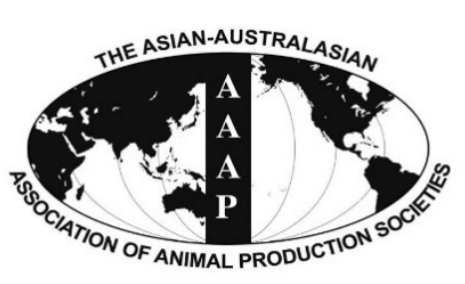

Open Access

Asian Australas. J. Anim. Sci.

Vol. 29, No. 1 : $73-79$ January 2016

http://dx.doi.org/10.5713/ajas.15.0464

www.ajas.info

pISSN 1011-2367 elSSN 1976-5517

\title{
Effect of Fodder Tree Species with Condensed Tannin Contents on In vitro Methane Production
}

\author{
Ernestina Gutiérrez Vázquez*, Leonardo Hernández Medina, Liliana Márquez Benavides, \\ Aureliano Juárez Caratachea, Guillermo Salas Razo, Armin Javier Ayala Burgos ${ }^{1}$, and Ruy Ortiz Rodríguez ${ }^{2}$ \\ Agriculture and Forestry Research Institute, Michoacan University of San Nicolas de Hidalgo, \\ Tarímbaro Michoacán, CP 58880, México
}

\begin{abstract}
The objective was to evaluate the effect of fodder tree species (FTS) with condensed tannin contents: Cordia elaeagnoides, Platymiscium lasiocarpum, Vitex mollis, and Haematoxylon brasiletto, on in vitro methane $\left(\mathrm{CH}_{4}\right)$ production at $24 \mathrm{~h}$ post incubation. The analysis was performed using the in vitro gas production technique, with three levels of inclusion/species: 600, 800, and $1,000 \mathrm{mg}$ and with 4 replicates/species/level of inclusion. The substrate was incubated at $39^{\circ} \mathrm{C}$, and the gas and $\mathrm{CH}_{4}$ production were recorded at 4, 8, 12, and 24 h post incubation. The data collected was analyzed through Pearson correlation, polinomial regression and fixed effects models. There were negative correlations between FTS-total gas volume $(\mathrm{r}=-0.40 ; \mathrm{p}<0.001)$; FTS-volume of $\mathrm{CH}_{4}$ produced $(\mathrm{r}=-0.40 ; \mathrm{p}<0.001)$ and between the inclusion level-volume of $\mathrm{CH}_{4}$ produced $(\mathrm{r}=-0.20 ; \mathrm{p}<0.001)$. As well as a positive correlation between hours post incubation-total gas volume $(\mathrm{r}=0.42 ; \mathrm{p}<0.001)$ and between hours post incubation-volume of $\mathrm{CH}_{4}$ produced $(\mathrm{r}=0.48 ; \mathrm{p}<0.001)$. The FTS: $C$. elaeagnoides, $V$. mollis, and $H$. brasiletto have potential, in the three inclusion levels analyzed, to reduce $\mathrm{CH}_{4}$ emission on in vitro trials $(>32.7 \%)$, taking into account the total $\mathrm{CH}_{4}$ production at $24 \mathrm{~h}$ of the forage used as reference (Avena sativa). It's suggested that C. elaeagnoides-according to its crude protein, neutral detergent fiber, and condensed

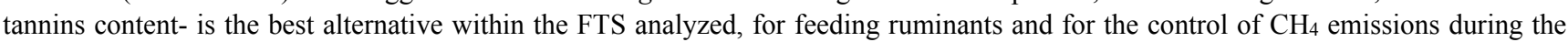
dry season. (Key Words: Fodder Tree Species, Condensed Tannins, Methane, In vitro)
\end{abstract}

\section{INTRODUCTION}

Currently, global warming is one of the most important crises in the world. Livestock, especially ruminants, are major contributors to this crisis and to the deterioration of the ozone layer by releasing large amounts of greenhouse gases into the atmosphere, including carbon dioxide $\left(\mathrm{CO}_{2}\right)$ and methane (Leng, 2010). So $\mathrm{CH}_{4}$ mitigation strategies in ruminants have focused on obtaining economic and environmental benefits (Thornton, 2010). The nutritional

\footnotetext{
* Corresponding Author: Ernestina Gutiérrez Vázquez. Tel: +52443-322-3500, E-mail: ernestinagvazquez@gmail.com

${ }^{1}$ Faculty of Veterinary Medicine and Zootechny, Autonomous University of Yucatan, CP 97315, México.

2 Faculty of Veterinary Medicine and Zootechny, Michoacan University of San Nicolas de Hidalgo, CP 58130, México.

Submitted May 28, 2015; Revised Jul. 6, 2015; Accepted Aug. 15, 2015
}

changes are more likely to be adopted by farmers because they increase the efficiency of feed utilization (Patra, 2012). Also, it has been shown that the use of different plants, such as trees and shrubs, have the potential to reduce $\mathrm{CH}_{4}$ emissions in ruminants (Patra et al., 2006).

In the region of Tierra Caliente Michoacán, Mexico, a great variety of tree species have been referred by ranchers and identified as fodder tree species (FTS) which livestock (ruminants) consume mainly during the dry season. The FTS with condensed tannin (CT) contents, such as Cueramo (Cordia elaeagnoides), Atuto (Vitex mollis), Granadillo (Platymiscium lasiocarpum), and Brasil (Haematoxylon brasiletto), are identified in the region of Tierra Caliente, Michoacán, México. These trees are considered promising species in the region, since they have 4 or more of the following attributes: i) produce fruit, with possible energy supply for livestock, ii) provide comfort to the animal since they remain green (fully or partially), iii) contain less than

Copyright (c) 2016 by Asian-Australasian Journal of Animal Sciences This is an open-access article distributed under the terms of the Creative Commons Attribution Non-Commercial License (http://creativecommons.org/licenses/by-nc/3.0/), which permits unrestricted non-commercial use, distribution, and reproduction in any medium, provided the original work is properly cited. 
$50 \%$ of neutral detergent fiber (NDF) and may be highly digestible, iv) have less than $5 \%$ of tannins, in order not to affect protein digestibility and $\mathrm{v}$ ) have a concentration equal or greater than $0.2 \%$ of phosphorus. Therefore, the objective of this study was to evaluate the effect of the FTS as a source to inhibit in vitro $\mathrm{CH}_{4}$ production.

\section{MATERIAL AND METHODS}

\section{Sampling of fodder tree species}

Samples of Cueramo, Atuto, Granadillo, and Brasil were collected in December 2012 from Zacapungamio, municipality of Carácuaro (N $18^{\circ} 57^{\prime} 46^{\prime \prime} \mathrm{W} 101^{\circ} 03^{\prime} 39^{\prime \prime}$ ) located in the region of Tierra Caliente, Michoacán, México. The municipality has elevations ranging from 300 to 1900 MASL. The area receives an annual rainfall of 800 to $1,000 \mathrm{~mm}$, an average annual temperature greater than $22^{\circ} \mathrm{C}$ and winter temperature ranging around $18^{\circ} \mathrm{C}$ (INEGI, 2000). The leaves of the FTS were harvested (approximately $4 \mathrm{~kg}$ of each tree was collected, consisting of a pool of several trees from the same species) and transported for laboratory analysis to the Institute of Agriculture and Forestry Research, located in the municipality of Tarímbaro Michoacán, México. The samples were air dried indoors followed by oven drying for $48 \mathrm{~h}$ at $70^{\circ} \mathrm{C}$ and ground to pass a $1 \mathrm{~mm}$ sieve prior to chemical analysis and in vitro incubations.

\section{Chemical composition analysis}

Ground samples were analyzed by standard procedures. Total ash (AOAC, 1995; method 942.05) and dry matter (DM) (AOAC, 1995; method 930.15), crude protein (CP)(AOAC, 1995; method 984.13) and ether extract (EE)(AOAC, 1995; method 920.29) were determined; neutral detergent fiber (NDF) and acid detergent fiber (ADF) using the procedure of Van Soest et al. (1991); CT and total phenols (TP) using the technique by Price and Butler (1997).

\section{In vitro gas production}

Rumen liquor donor: Rumen fluid was obtained from a Creole bull (400 kg BW), which was fed oat hay (ad libitum), supplemented with minerals and had access to clear water (to simulate the feeding conditions during the dry season). The ruminal inoculum was obtained before the morning feeding (07:00 am) using a rumen fluid extraction equipment designed by Geishauser (1993). The collected rumen fluid was placed in warm insulated thermos $\left(39^{\circ} \mathrm{C}\right)$ under anaerobic conditions and transported immediately to the laboratory. In the laboratory it was strained through four layers of cheesecloth and kept at $39^{\circ} \mathrm{C}$ under a $\mathrm{N}_{2}$ atmosphere until utilization.
Culture medium and in vitro incubations: The culture medium and the in vitro gas production test were carried out according to Menke and Steingass (1988), modified by using $70 \mathrm{~mL}$ serum bottles instead of calibrated glass syringes. The culture media consist of distilled water, macro and micromineral solution, buffer solution, resazurin and a reducing solution. It was prepared and inoculated using aseptic and anaerobic techniques. For the fermentation, 600, 800 and 1,000 mg of each species were incubated (with 4 replicates/species/level of inclusion) along with $10 \mathrm{~mL}$ of rumen fluid and $20 \mathrm{~mL}$ of the culture media. Additionally, serum bottles containing oat hay (without CT contents) were incubated in quadruplicate, serving as control for the incubation, no blanks were included. The bottles were sealed with rubber stoppers (Suba-Seal rubber septa network \# 33, Sigma Aldrich, Milwaukee, WI, USA), the biogas in the headspace was flushed with $\mathrm{N}_{2}$ and the bottles were incubated without agitation at $39^{\circ} \mathrm{C}$ for a period of 24 h. After each reading $(4,8,12,24 \mathrm{~h}$ post incubation) the bottles were agitated and returned to the incubator.

Determination of gas and methane production: To quantify the $\mathrm{CH}_{4}$ production a gas chromatograph (GC) was used (Varian CP-3800, Walnut Creek, CA, USA), equipped with a flame ionization detector and a packed column Silica Gel 60/80 dimensions $18^{\prime} \times 1 / 8^{\prime \prime}$ stainless steel, the operating temperatures of the injector, the detector and the column were $170^{\circ} \mathrm{C}, 170^{\circ} \mathrm{C}$, and $90^{\circ} \mathrm{C}$ respectively. With $\mathrm{N}_{2}$ as the carrier gas at a flow rate of $30 \mathrm{~mL} / \mathrm{min}$. For analysis of $\mathrm{CH}_{4}$ production, $30 \mu \mathrm{L}$ were obtained from the headspace of each bottle with a gas-tight syringe (Hamilton Company, Reno, NV, USA; chromatography syringes) and injected in the $\mathrm{GC}$ at $4,8,12$, and $24 \mathrm{~h}$ post incubation. Gas production was measured using a biogas measurement system (Beuvink et al., 1992).

\section{Statistical analysis}

With the gathered data, a database was developed for statistical analysis using Pearson correlation for continuous variables, the omega squared statistics of Hays $\left(\omega^{2}\right)$ to determine the degree of association between nominal and continuous variables, polynomial regression, and fixed effects models. The differences between treatments were tested using a least square means test (LSMEANS). The statistical package used was Scientific Applied Statistics (SAS, 2000). The model used to estimate polynomial methane gas production/FTS was:

$$
\hat{\mathrm{Y}}_{\mathrm{i}}=\beta_{0}+\beta_{1} \times \mathrm{N}+\beta_{2} \times \mathrm{t}+\beta_{3} \times \mathrm{t}^{2}
$$

Where, $\hat{\mathrm{Y}}_{\mathrm{i}}=\mathrm{CH}_{4}$ production from: oat hay, Cueramo, Granadillo, Atuto, and Brasil, N = FTS inclusion level, $\mathrm{t}=$ hours post-incubation. 
While for the fixed effects analysis the following model was used:

$$
\mathrm{Y}_{\mathrm{ij}}=\mu+\mathrm{T}_{\mathrm{i}}+\mathrm{E}_{\mathrm{ij}}
$$

Where, $\mathrm{Y}_{\mathrm{ij}}=$ in vitro $\mathrm{CH}_{4}$ production at $24 \mathrm{~h}, \mu=$ overall mean, $T_{i}=$ fixed effect of the ith treatment with ${ }_{i}=$ oat hay at 600,800 , and 1,000 mg inclusion; Cueramo at 600,800 , and 1,000 mg inclusion; ... Brasil at 600,800 , and 1,000 $\mathrm{mg}$ inclusion, $\mathrm{E}_{\mathrm{ij}}=$ error $(\mathrm{NID} \sim 0, \delta 2)$.

\section{RESULTS}

\section{Chemical composition}

In order to evaluate the nutritional quality of the FTS during the dry season, the chemical composition analysis was done. Ash content in two FTS was $>100 \mathrm{~g} / \mathrm{kg}$ DM (Table 1). CP from the four FTS was higher than the reference feed (oat hay), and varied from $88 \mathrm{~g} / \mathrm{kg} D \mathrm{DM}$ in Granadillo to $167 \mathrm{~g} / \mathrm{kg}$ DM in Cueramo. The EE was very similar in all FTS but was much higher (32 to $35 \mathrm{~g} / \mathrm{kg} \mathrm{DM}$ ) compared to the reference $(6 \mathrm{~g} / \mathrm{kg} \mathrm{DM})$. NDF in the FTS was very similar, ranging from $409 \mathrm{~g} / \mathrm{kg}$ DM in Cueramo to $498 \mathrm{~g} / \mathrm{kg}$ DM in Atuto. ADF varied from $220 \mathrm{~g} / \mathrm{kg}$ DM in Cueramo to $339 \mathrm{~g} / \mathrm{kg}$ DM in Atuto. Both NDF and ADF in FTS were lower than the reference oat hay with 633 and $392 \mathrm{~g} / \mathrm{kg}$ DM, respectively.

CT and TP varied among the FTS (Table 1). Brasil showed the highest concentration of both CT and TP with 119 and $196 \mathrm{~g} / \mathrm{kg} \mathrm{DM}$, respectively; in comparison with Cueramo, which contained the lowest concentrations of CT and TP with 0.2 and $22 \mathrm{~g} / \mathrm{kg} \mathrm{DM}$, respectively.

\section{Effect of fodder tree species on in vitro $\mathrm{CH}_{4}$ production}

The degree of association observed between FTS and total volume of gas in vitro $\left(\omega^{2}=0.57 ; \mathrm{p}<0.05\right)$ and between FTS and volume of $\mathrm{CH}_{4}$ produced $\left(\omega^{2}=0.53, \mathrm{p}<0,05\right)$ was moderate $(<70 \%)$ (Table 2). Implying that $57 \%$ and $53 \%$ of the variance in the volume of gas and $\mathrm{CH}_{4}$ produced in vitro, respectively, can be attributed to the presence of the FTS analyzed (Figure 1). The total average of $\mathrm{CH}_{4}$ production at $24 \mathrm{~h}$ was $44.7 \pm 28 \mathrm{~mL} / \mathrm{g} \mathrm{DM}$. Average affected by treatment
Table 2. Association degree $\left(\omega^{2}\right)$ between nominal and continuous variables and Pearson correlation coefficients for continuous variables: gas volume and methane $\left(\mathrm{CH}_{4}\right)$

\begin{tabular}{lccccc}
\hline & FTS & $\begin{array}{c}\text { Inclusion } \\
\text { level }\end{array}$ & \multicolumn{2}{c}{$\begin{array}{c}\text { Hours post } \\
\text { incubation }\end{array}$} & $\begin{array}{c}\text { Gas } \\
\text { volume }\end{array}$ \\
\cline { 2 - 6 } & $\omega^{2}$ & $\omega^{2}$ & $\omega^{2}$ & $\mathrm{r}$ & $\mathrm{R}$ \\
\hline Gas volume & $0.57^{* *}$ & $0.04^{* *}$ & $0.30^{* *}$ & $0.42^{* *}$ & 1.0 \\
$\mathrm{CH}_{4}$ volume & $0.53^{* *}$ & $0.12^{* *}$ & $0.24^{* *}$ & $0.48^{* *}$ & $0.87^{* *}$ \\
\hline
\end{tabular}

FTS, fodder tree species; $\omega^{2}$, Omega squared statistics; r, pearson correlation coefficients.

$* * \mathrm{p}<0.001$.

(FTS and inclusion level; $\mathrm{p}<0.001$ ), hours post-incubation $(\mathrm{p}<0.001)$ and the interaction between treatment and hours post incubation $(\mathrm{p}<0.001)$.

Regarding the effect of the treatment on total $\mathrm{CH}_{4}$ production (at $24 \mathrm{~h}$ post-incubation), it was found that $\mathrm{CH}_{4}$ production was lower $(\mathrm{p}<0.05)$ with the species Cueramo and Brasil at the three inclusion levels analyzed (Table 3, Figure 2). The percent in $\mathrm{CH}_{4}$ reduction from the FTS compared to oat hay (reference) showed a trend among the three levels of inclusion (Table 4). Granadillo was the species with the least $\mathrm{CH}_{4}$ inhibited with a maximum of $18.6 \%$.

\section{DISCUSSION}

The use of plant secondary metabolites has been previously studied for the inhibition of $\mathrm{CH}_{4}$ production in ruminants. Hess et al. (2006) established that the strategic use of tannins is a means to limit $\mathrm{CH}_{4}$ emission $13 \%$. This is consistent with other researchers (Min et al., 2006), who determined that CT decreases (in a dose-dependent response) the rate of in vitro gas production. Dietary $\mathrm{CP}$ and NDF concentrations influence the amount of substrate organic matter fermented and the short chain fatty acids that are produced (Njidda and Nasiru, 2010). Crude protein concentrations below the threshold of $70 \mathrm{~g} \mathrm{CP} / \mathrm{kg} \mathrm{DM}$, restrict microbial activity due to a lack of nitrogen (Hariadi and Santoso, 2010). However, protein levels above this threshold, as seen in this study, are considered to enhance microbial multiplication in the rumen, thus improving fermentation (Njidda and Nasiru, 2010).

Table 1. Chemical composition and secondary metabolites of the experimental plants $(\mathrm{g} / \mathrm{kg} \mathrm{DM})^{1}$

\begin{tabular}{lccccccc}
\hline Species & Ash & Crude protein & Ether extract & NDF & ADF & CT & TP \\
\hline Oat hay & 97 & 78 & 6 & 633 & 392 & ND & ND \\
Atuto & 99 & 121 & 33 & 498 & 339 & 10.1 & 92.2 \\
Cueramo & 149 & 167 & 35 & 409 & 220 & 0.2 & 22.1 \\
Granadillo & 105 & 88 & 35 & 476 & 270 & 0.9 & 44.3 \\
Brasil & 93 & 112 & 32 & 488 & 303 & 119.3 & 196.2 \\
\hline
\end{tabular}

DM, dry matter; NDF, neutral detergent fiber; ADF, acid detergent fiber; CT, condensed tannins, equivalent to catequin; TP, total phenols, equivalent to gallic acid; ND, not detected.

${ }^{1}$ Samples pooled $(n=4)$. 


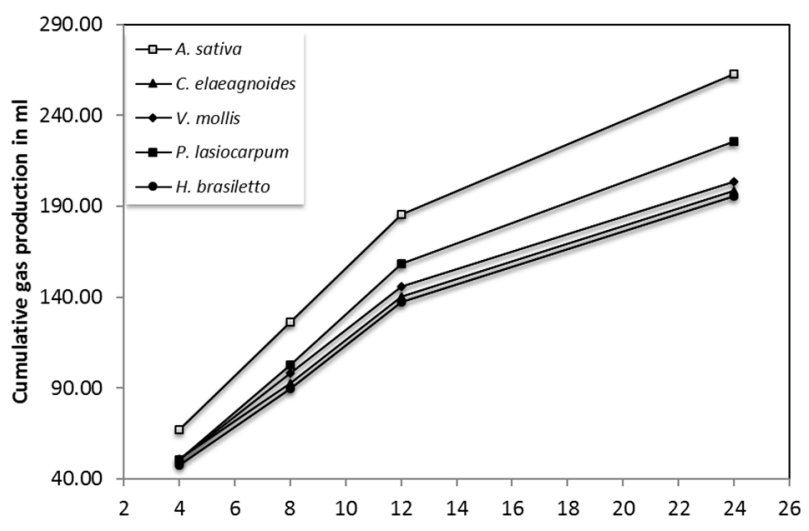

(a)

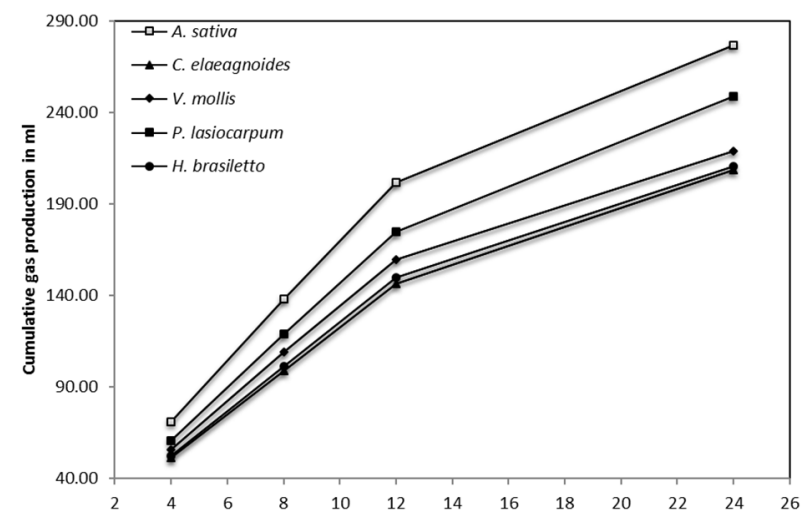

(b)

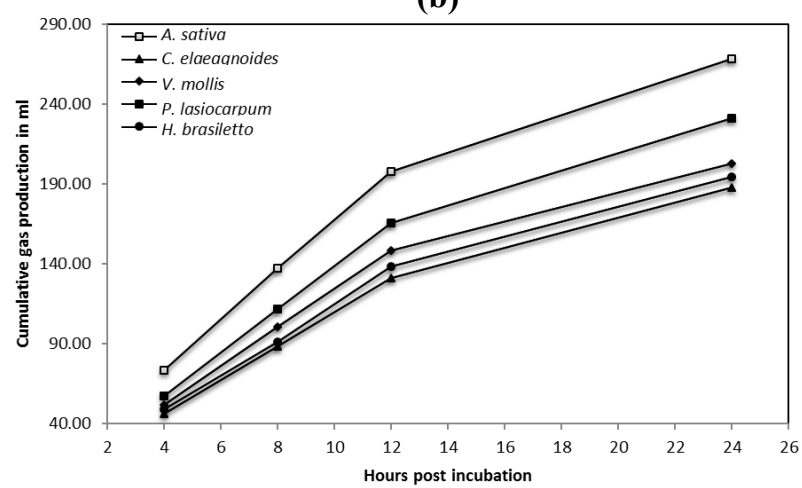

(c)

Figure 1. Cumulative gas production at $24 \mathrm{~h}$ post incubation with (a) 1,000 mg, (b) $800 \mathrm{mg}$ and (c) $600 \mathrm{mg}$ of FTS and with oat hay as reference forage. FTS, fodder tree species.

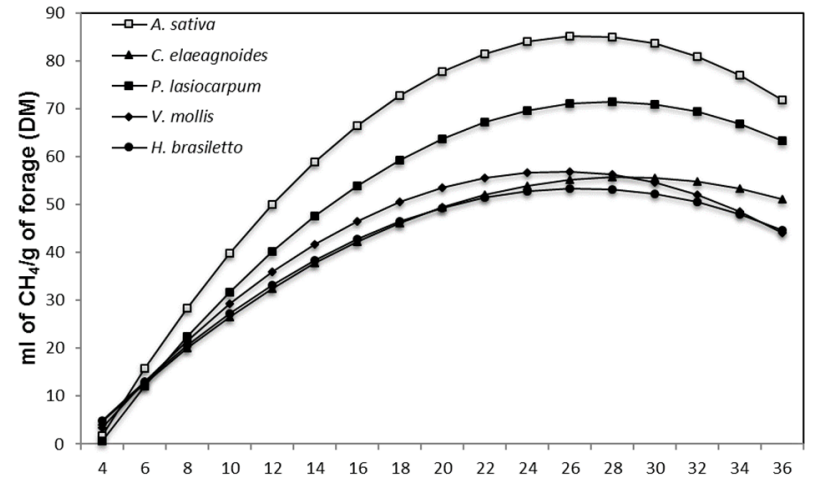

(a)

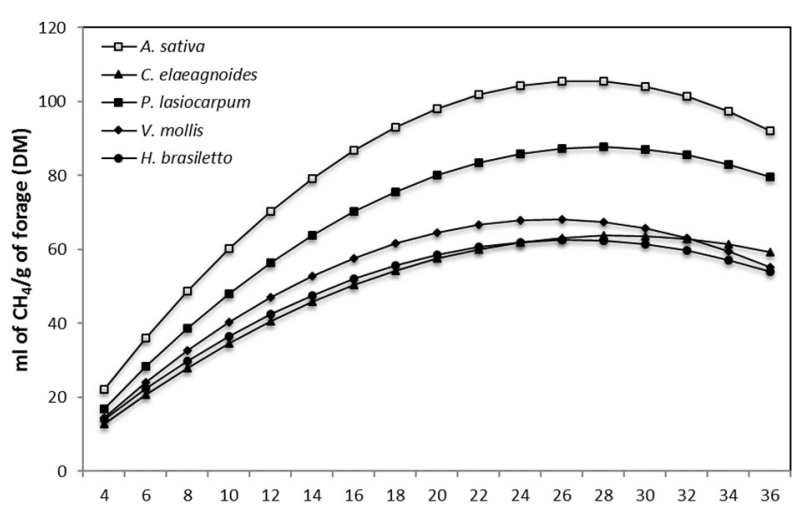

(b)

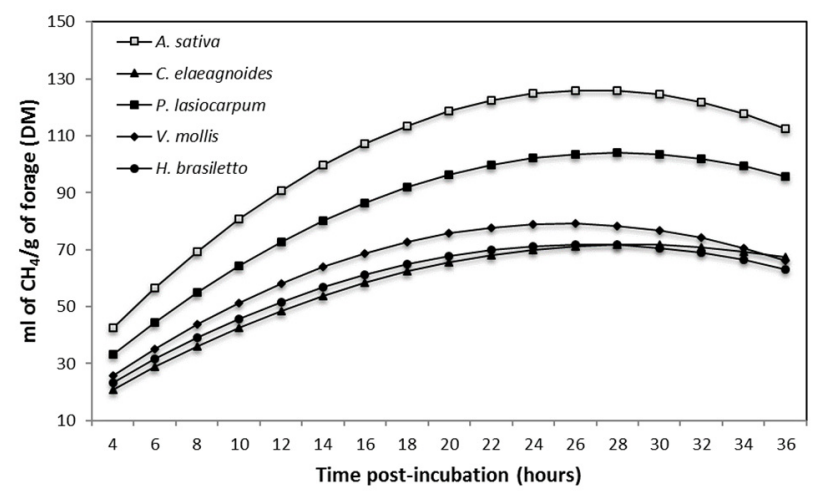

(c)

Figure 2. $\mathrm{CH}_{4}$ production at $24 \mathrm{~h}$ post-incubation with (a) 1,000 $\mathrm{mg}$, (b) $800 \mathrm{mg}$ and (c) $600 \mathrm{mg}$ of FTS and with oat hay as reference forage. FTS, fodder tree species.

Table 3. Polynomial regression coefficients to determine $\mathrm{CH}_{4}$ volume produced at $24 \mathrm{~h}$ post incubation according to the species, inclusion level and $\mathrm{h}$ post incubation

\begin{tabular}{lcccc}
\hline Species & Intercept & Inclusion level & Hours & Hours $^{2}$ \\
& $\beta_{0}$ & $\beta_{1}$ & $\beta_{2}$ & $\beta_{3}$ \\
\hline Oat hay & $71.9596639^{* *}$ & $-102.0765625^{* *}$ & $8.5966661^{* *}$ & $-0.1601629^{* *}$ \\
Cueramo & $27.21563076^{* *}$ & $-40.3234375^{* *}$ & $4.80322169^{* *}$ & $-0.08381^{* *}$ \\
Atuto & $37.16741022^{* *}$ & $-55.55^{* *}$ & $5.92138755^{* *}$ & $-0.11633489^{* *}$ \\
Granadillo & $56.30807551^{* *}$ & $-81.303125^{* *}$ & $6.91893934^{* *}$ & $-0.12409861^{* *}$ \\
Brasil & $32.21148941^{* *}$ & $-46.175^{* *}$ & $5.08404293^{* *}$ & $-0.09595419^{* *}$ \\
\hline
\end{tabular}

** $\mathrm{p}<0.001$. 
Table 4. $\mathrm{CH}_{4}$ reduction according to the FTS, inclusion level and hour of maximum production with respect to oat hay

\begin{tabular}{lccc}
\hline Species & $\begin{array}{c}\text { Inclusion level } \\
(\mathrm{mg} \mathrm{DM})\end{array}$ & $\begin{array}{c}\mathrm{MPCH}_{4} * \\
(\mathrm{~mL})\end{array}$ & $\begin{array}{c}\mathrm{CH}_{4} \text { reduction } \\
(\%)\end{array}$ \\
\hline Oat hay & 1,000 & 66.6 & - \\
& 800 & 109.9 & - \\
Atuto & 600 & 136.1 & - \\
Granadillo & 1000 & 44.8 & 32.7 \\
Cueramo & 1000 & 54.2 & 18.6 \\
Brasil & 1000 & 43.1 & 35.3 \\
Atuto & 1000 & 41.9 & 37.1 \\
Granadillo & 800 & 72.6 & 33.9 \\
Cueramo & 800 & 90.6 & 17.6 \\
Brasil & 800 & 66.2 & 39.8 \\
Atuto & 600 & 63.9 & 41.9 \\
Granadillo & 600 & 85.8 & 37.0 \\
Cueramo & 600 & 112.4 & 17.4 \\
Brasil & 600 & 76.2 & 44.0 \\
\hline
\end{tabular}

FTS, fodder tree species.

* Average $\mathrm{CH}_{4}$ production from the start of incubation to $24 \mathrm{~h}$ post incubation.

Nevertheless, Jayanegara et al. (2009) suggest that CT, in synergy with fiber digestion, decrease $\mathrm{CH}_{4}$ production. The FTS in the region of Tierra Caliente, Michoacán, contain concentrations of $\mathrm{CT}, \mathrm{CP}$ concentrations above the threshold and lower NDF concentrations than the rough forages used as feed during the dry season; thus, the four species used in our study were selected in order to test their capacity to decrease $\mathrm{CH}_{4}$ production in vitro.

\section{Effect of fodder tree species on in vitro $\mathrm{CH}_{4}$ production}

Total $\mathrm{CH}_{4}$ production decreased $(\mathrm{mL} / \mathrm{g} \mathrm{DM})$ as the $\mathrm{CT}$ content increased, which occurred with the species Granadillo, Atuto, and Brasil. This was consistent with Bhatta et al. (2009) and Jayanegara et al. (2011); they reported a negative correlation between tannin content and $\mathrm{CH}_{4}$ production. Similarly, other researches (Meagher et al., 2005; O'kiely et al., 2011) concluded that a greater quantity of secondary metabolites present in FTS will lead to a lower in vitro gas and $\mathrm{CH}_{4}$ production.

The degree of association between level of inclusion and volume of $\mathrm{CH}_{4}$ produced with the FTS was weak $\left(\omega^{2}=\right.$ $0.12 ; \mathrm{p}<0.001$ ), thus $12 \%$ of the variance in $\mathrm{CH}_{4}$ production can be explained by the level of inclusion of the FTS analyzed. However, in other studies (Bhatta et al., 2009; Huang et al., 2010) it was reported that the greater the inclusion level of CT, the lower the $\mathrm{CH}_{4}$ produced. This is consistent with the results found in this experiment (Table 4). As for the association between hours post-incubation and volume of gas produced $\left(\omega^{2}=0.30 ; \mathrm{p}<0.001\right.$ and $\mathrm{r}=$ $0.42 ; \mathrm{p}<0.001)$ and between hours post-incubation and volume of $\mathrm{CH}_{4}$ produced $\left(\omega^{2}=0.24 ; \mathrm{p}<0.001\right.$ and $\mathrm{r}=0.48$, $\mathrm{p}<0.001$ ), these determined that as the hours of incubation elapse, gas volume and $\mathrm{CH}_{4}$ production increase. Similarly, Abdalla et al. (2012) determined that the profile of cumulative gas production at $24 \mathrm{~h}$ is in function of the hours post-incubation, and depends on the CT concentration.

The reduction in $\mathrm{CH}_{4}$ production by the species Brasil is attributed to its high CT content. Tannins have been shown to reduce $\mathrm{CH}_{4}$ production by reducing fiber digestion (Tiemann et al., 2008); binding with proteins thus reducing degradation of the plant protein in the rumen and through the direct inhibition of the growth of methanogens (Tavendale et al., 2005). It has been established that a greater concentration of $\mathrm{CT}$ will lead to a lower total $\mathrm{CH}_{4}$ production (Huang et al., 2010). Carulla et al. (2005) attributed the inhibition of $\mathrm{CH}_{4}$ production from the species A. mearnsii to the direct effect of the CT.

The FTS Cueramo showed the least concentration of CT in comparison to the other species analyzed, but had a greater concentration of CP $(167 \mathrm{~g} / \mathrm{kg} \mathrm{DM})$ and a lower concentration of NDF ( $409 \mathrm{~g} / \mathrm{kg} \mathrm{DM})$ compared to the rest of the FTS and oat hay (Table 1). The CP and the NDF content in Cueramo may be the responsible for the inhibition of $\mathrm{CH}_{4}$ production. Kume (2002) suggest that $\mathrm{CH}_{4}$ reduction is attributed to a low content of NDF and a high content of CP. This is consistent with Meagher et al. (2005), they analyzed the species M. sativa, without CT, with $348 \mathrm{~g}$ of NDF/ $/ \mathrm{kg}$ DM and $301 \mathrm{~g}$ of $\mathrm{CP} / \mathrm{kg} \mathrm{DM}$, which led to a reduction in the volume of $\mathrm{CH}_{4}$ produced. Jayanegara et al. (2009) determined that high concentrations of NDF in forages causes an increase of $\mathrm{CH}_{4}$ production, due to a shift in the proportion of short chain volatile fatty acids towards acetate, which produces more $\mathrm{H}_{2}$.

It is generally accepted that feedstuffs which have higher gas production tend to have higher $\mathrm{CH}_{4}$ production per gram DM incubated (Njidda and Nasiru, 2010; Jayanegara et al., 2011). This tendency was evident in the forages used in this study. This relationship is suggested to be a reflection of feed digestibility (Holtshausen et al., 2009). Increasing cell wall content (i.e. NDF and ADF) is considered to suppress microbial activity through a reduction in the availability of rapidly fermented carbohydrates (Wilson and Hatfield, 1997). This in turn, is negatively correlated with gas production (Njidda and Nasiru, 2010). This is consistent with the results obtained from the forage used as reference which had high concentrations of NDF (632 g/kg DM).

However, Getachew et al. (1998) indicate that the concentration level of the substrate reduces ruminal gas production per gram of DM, due to the low proportion of microorganisms in relation to the substrate or due to the buffer depletion. This could be associated with the decrease in $\mathrm{CH}_{4}$ production by Cueramo and Brasil analyzed at a concentration of $1,000 \mathrm{mg}$. 


\section{CONCLUSIONS}

The species with the greatest potential in $\mathrm{CH}_{4}$ reduction were Brasil and Cueramo. The FTS with the most $\mathrm{CH}_{4}$ produced at $24 \mathrm{~h}$ of incubation was Granadillo in the three inclusion levels $(600,800$, and $1,000 \mathrm{mg})$. According to its $\mathrm{CP}$, NDF, and CT content, Cueramo is the best alternative for ruminant nutrition during the dry season in the region of Tierra Caliente Michoacán and showed the best $\mathrm{CH}_{4}$ reduction potential during the in vitro trials. However, there is a great variety of FTS which are used as a source of feed during the dry season in the region and with a CT content that will have no negative effects in ruminant nutrition. Further research is needed toward finding better alternatives in ruminant feeding and to determine how the FTS in the region of Tierra Caliente Michoacán can inhibit $\mathrm{CH}_{4}$ production.

\section{CONFLICT OF INTEREST}

We certify that there is no conflict of interest with any financial organization regarding the material discussed in the manuscript.

\section{ACKNOWLEDGMENTS}

The corresponding author wish to thank Juan M. Sánchez-Yáñez for the insights and technical contributions to this work and is grateful to the National Council of Science and Technology (CONACYT) for the grant received (387906/253748).

\section{REFERENCES}

Abdalla, A. L., H. Louvandini, S. M. A. H. Sallam, I. C. S. Bueno, S. M. Tsai, and A. V. O. Figueira. 2012. In vitro evaluation, in vivo quantification, and microbial diversity studies of nutritional strategies for reducing enteric methane production. Trop. Anim. Health Prod. 44:953-964.

AOAC. 1995. Official Methods of Analysis, 16th ed. Association of Official Analytical Chemists, Arlington, VA, USA.

Beuvink, J., S. Spoelstra, and R. Hogendorp. 1992. An automated method for measuring time course of gas production of feedstuffs incubated with buffered rumen fluid. Neth. J. Agric. Sci. 40:401-407.

Bhatta, R., Y. Uyeno, K. Tajima, A. Takenaka, Y. Yabumoto, I. Nonaka, O. Enishi, and M. Kurihara. 2009. Difference in the nature of tannins on in vitro ruminal methane and volatile fatty acid production and on methanogenic archaea and protozoal populations. J. Dairy Sci. 92:5512-5522.

Carulla, J. E., M. Kreuzer, A. Machmüller, and H. D. Hess. 2005. Supplementation of Acacia mearnsii tannins decreases methanogenesis and urinary nitrogen in forage-fed sheep. Aust. J. Agric. Res. 56:961-970.
Geishauser, T. 1993. An instrument for collection and transfer of ruminal fluid and for administration of water soluble drugs in adult cattle. Bovine Pract. 27:38-42.

Getachew, G., M. Blümmel, H. P. S. Makkar, and K. Becker. 1998. In vitro gas measuring techniques for assessment of nutritional quality of feeds: A review. Anim. Feed Sci. Technol. 72:261281.

Hariadi, B. T. and B. Santoso. 2010. Evaluation of tropical plants containing tannin on in vitro methanogenesis and fermentation parameters using rumen fluid. J. Sci. Food Agric. 90:456-461.

Hess, H. D., T. T. Tiemann, F. Noto, J. E. Carulla, and M. Kreuzer. 2006. Strategic use of tannins as means to limit methane emission from ruminant livestock. Int. Congr. Ser. 1293:164167.

Holtshausen, L., A. V. Chaves, K. A. Beauchemin, S. M. McGinn, T. A. McAllister, P. R. Cheeke, and C. Benchaar. 2009. Feeding saponin-containing Yucca schidigera and Quillaja saponaria to decrease enteric methane production in dairy cows. J. Dairy Sci. 92:2809-2821.

Huang, X. D., J. B. Liang, H. Y. Tan, R. Yahya, B. Khamseekhiew, and Y. W. Ho. 2010. Molecular weight and protein binding affinity of Leucaena condensed tannins and their effects on in vitro fermentation parameters. Anim. Feed Sci. Technol. 159: 81-87.

INEGI (National Institute of Statistics, Geography and Informatics). 2000. Encyclopedia of the Municipalities of Michoacán, México. 30-33.

Jayanegara, A., E. Wina, C. R. Soliva, S. Marquardt, M. Kreuzer, and F. Leiber. 2011. Dependence of forage quality and methanogenic potential of tropical plants on their phenolic fractions as determined by principal component analysis. Anim. Feed Sci. Technol. 163:231-243.

Jayanegara, A., N. Togtokhbayar, H. P. S. Makkar, and K. Becker. 2009. Tannins determined by various methods as predictors of methane production reduction potential of plants by an in vitro rumen fermentation system. Anim. Feed Sci. Technol. 150: 230-237.

Kume, S. 2002. Establishment of profitable dairy farming system on control of methane production in Hokkaido region. In Greenhouse Gases and Animal Agriculture (Eds. J. Takahashi and B. A. Young). Elsevier Science, Obihiro, Japan. 87-94.

Leng, R. A. 2010. Decline in available world resources implications for livestock production system. FAO/IAEA Sustainable Improvement of Animal Production and Health, Rome, Italy. 11-19.

Meagher, L., M. Tavendale, D. Pacheco, N. Walker, G. Attwood, and S. Sivakumaran. 2005. Methane production from in vitro rumen incubations with Lotus pedunculatus and Medicago sativa, and effects of extractable condensed tannin fractions on methanogenesis. Anim. Feed Sci. Technol. 123-124(Part 1): 403-419.

Menke, K. H. and H. Steingass. 1988. Estimation of the energetic feed value obtained from chemical analysis and in vitro gas production using rumen fluid. Anim. Res. Dev. 28:7-55.

Min, B. R., W. E. Pinchak, R. C. Anderson, J. D. Fulford, and R. Puchala. 2006. Effects of condensed tannins supplementation level on weight gain and in vitro and in vivo bloat precursors in steers grazing winter wheat. J. Anim. Sci. 84: 2546-2554. 
Njidda, A. A. and A. Nasiru. 2010. In vitro gas production and dry matter digestibility of tannin-containing forages of semiarid region of north-eastern Nigeria. Pakistan J. Nutr. 9:60-66.

O'Kiely, P., A. Navarro-Villa, M. O'Brien, S. López, and T. M. Boland. 2011. In vitro rumen methane output of red clover and perennial ryegrass assayed using the gas production technique (GPT). Anim. Feed Sci. Technol. 168:152-164.

Patra, A. K. 2012. Enteric methane mitigation technologies for ruminant livestock: A synthesis of current research and future directions. Environ. Monit. Assess. 184:1929-1952.

Patra, A. K., D. N. Kamra, and N. Agarwal. 2006. Effect of plants containing secondary metabolites on in vitro methanogenesis, enzyme profile and fermentation of feed with rumen liquor of buffalo. Anim. Nutr. Feed Technol. 6:203-213.

Price, M. L. and L. G. Butler. 1997. Rapid visual estimation and spectrophotometric determination of tannin content of sorghum grain. J. Agric. Food Chem. 25:1268-1273.

SAS (Statistical Analysis System). 2000. SAS User's Guide, Version 8.1. Cary, NC. USA.
Tavendale, M. H., L. P. Meagher, D. Pacheco, N. Walker, G. T. Attwood, and S. Sivakumaran. 2005. Methane production from in vitro rumen incubations with Lotus pedunculatus and Medicago sativa, and effects of extractable condensed tannin fractions on methanogenesis. Anim. Feed Sci. Technol. 123:403-419.

Thornton, P. K. 2010. Livestock production: recent trends, future prospects. Phil. Trans. R. Soc. B. 365:2853-2867.

Tiemann, T. T., C. E. Lascano, H-R. Wettstein, A. C. Mayer, M. Kreuzer, and H. D. Hess. 2008. Effect of the tropical tanninrich shrub legumes Calliandra calothyrsus and Flemingia macrophylla on methane emission and nitrogen and energy balance in growing lambs. Animal 2:790-799.

Van Soest, P. J., J. B. Robertson, and B. A. Lewis. 1991. Methods for dietary fiber, neutral detergent fiber, and nonstarch polysaccharides in relation to animal nutrition. J. Dairy Sci. 74: 3583-3597.

Wilson, J. R. and R. D. Hatfield. 1997. Structural and chemical changes of cell wall types during stem development: Consequences for fibre degradation by rumen microflora. Aust. J. Agric. Res. 48:165-180. 